\title{
NORTH EUROPEAN EXPORT INDUSTRY AND THE SHADOWS OF SULPHUR DIRECTIVE
}

\author{
Esa Hämäläinen ${ }^{1}$, Olli-Pekka Hilmola ${ }^{2}$, Andres Tolli ${ }^{3}$ \\ ${ }^{1}$ University of Turku \\ Brahea Centre, FIN-20014 Turku, Finland \\ e-mail: esa.hamalainen@utu.fi \\ ${ }^{2}$ Lappeenranta University of Technology, Kouvola Unit \\ Prikaatintie 9, FIN-45100 Kouvola, Finland \\ Fax: +358 5344 4009, e-mail: olli-pekka.hilmola@lut.fi \\ ${ }^{3}$ Tallinn University of Technology, Estonian Maritime Academy \\ Kopli 101, 11712 Tallinn, Estonia \\ Ph.:+372 5071 899, e-mail: andres.tolli@ttu.ee
}

\begin{abstract}
EU Directive of MARPOL Annex VI and its economic impact on the Nordic paper industry is theme of this research work. Empirical data for analysis purposes was gained from a large Nordic paper mill that exports bulk products mainly to Europe ( $70 \%$ of its volume). The study shows that in the end the industry's location still has an economical effect, and that the location has a distinct impact on competition through rising transportation costs. Environmental regulation continues and fosters long-term upwards trajectory of transportation cost, which has been experienced by the paper mill earlier during years 2001-2009. Sulphur regulation change to cleaner grades of maritime diesel did not turn as heavy cost increase in the 2015 , however, possibility to gain cost benefits in rapidly deteriorating oil markets were not reached either. Therefore, in depressed industrial product markets, like paper industry, implications were such that margins of export industry remained low.
\end{abstract}

Keywords: Sulphur, Transportation, Paper industry, IMO, Sea freights

\section{Introduction}

The main purpose of this paper is to explore from the viewpoint of economic geography, how manufacturing and especially logistic costs impact gross margins. These are critical for sustainability and survival of bulk industries. Research focuses to analyze, how the environmental decisions could impact logistics and sea transportation costs in the Baltic Sea and the gross margins of paper manufacturing in Northern Region of Europe (see e.g. EU 2005 and 2012; Hamalainen 2011b; Kalli 2012; Finnish Transport Safety Agency 2013). The new environmental directives (EU 2005 and 2012; IMO 2014) can bring new challenges to the Nordic bulk and thus paper industry in the form of additional sea freight costs. Also Holmgren et al. (2014) state that the implementation of MARPOL Annex VI in the North and Baltic Sea SECA has raised economic concerns among shippers and ship owners as well as spurred policymakers to appeal to various interests, such as citizen health, export industry competitiveness, and consumer prices.

Paper manufacturing industry has been examined marginally from the viewpoint of economy geography. As to the paper industry, economical or business researchers have published few papers in academic journals (see e.g. Lähtinen 2007; Arlbjørn et al. 2008; Koskinen 2009; Hetemäki and Hänninen 2009; Hämäläinen and Tapaninen 2008 and 2010; Hämäläinen, 2011a, 2011b and 2011c). Hämäläinen, in his empirical case studies, showed the fundamental changes, which took place in the Finnish paper industry during the years 2001-2009 and evaluated their main reasons. Hämäläinen (2011b) found that transportation costs clearly increase in a certain spatial context in the European market. One key innovation in research sense was to show that transportation costs and customer order volumes are in definite dependency. In an earlier paper, Hämäläinen and Tapaninen (2010) showed that in Finland there are big monthly variations in paper deliveries as well as in customer levels. These export variations are probably one reason for long and costly warehousing times presented in Koskinen and Hilmola (2008) and Koskinen (2009).

The Finnish paper industry was originally derived and developed due to many competitive advantages (see e.g. Diesen 1998; Dieter and Englert 2007): availability of reasonable fiber; inexpensive hydro energy; large and efficient paper machines; skilled personnel; and a growing demand in the main markets until the late $20^{\text {th }}$ century (Hämäläinen et al., 2015). Since year 2006 the economic situation in the 
Finnish paper industry could be characterized by declining demand and simultaneous increase in costs, especially for the main raw materials (Hämäläinen 2011b). These soaring costs together with dwindling prices have led to unprofitable production; this in turn resulting in mill shutdowns even in Finland between the years 2001-2010 (see e.g. Hämäläinen 2011b). The present oversupply in the European paper markets is circa 5 million tons, and it creates extensive flexibility in sales-purchase prices between buyers and sellers (Anonymous, 2014).

In addition to decreasing demand and crumbling paper prices, there are also other visible and difficult challenges, which are coming into effect in the Northern Europe. Probably the most significant of new challenges are the environmental decisions, which are conducted by IMO and the European Parliament (see IMO 2014; EU 2005, 2012). The first of these directives force ship owners to decrease the polluting sulphur emissions from their ships in the SECA-region from 2015 onward. This means simply that a change of fuel must be made from the heavy fuel oil (HFO, max sulphur content $1.0 \%$ ) to the cleaner yet more expensive marine gas oil (MGO, max. sulphur content $0,1 \%$ ). This change is generally expected to affect sea transportation costs in the Baltic Sea Region (see e.g. Kalli et al., 2009; Notteboom 2011; Kalli 2012; Hilmola 2013; Hilmola, 2015). Nevertheless, these decisions aside, Cullinane (2012) argues that even if shipping is a viable modal alternative in relative terms and in most contexts, and it retains significant environmental advantages over other modes. According to Jiang et al. (2014), the adoption of sulphur reduction measures has strong negative influence on ship owners and government, but positive impact on society through resulting in cleaner air. A solely private perspective on the economic performance of reduction measures is far from comprehensive. Gallagher (2010), Bruckner-Menchelli (2011) and Einemo (2013) address that there are multiple fuel types available to replace the heavy fuel oil (HFO), and they all have different advantages and constraints. The most obvious and easiest solution is to start to use the marine gas oil (MGO), even though it is an expensive choice (see Alhosalo, 2013). However, there have also been few trials with the liquefied natural gas (LNG), methanol and biofuels. The LNG is considered to be the most plausible choice after the MGO, and it is also the most tested low-sulphur fuel in shipping; there are round 30 ships operating on LNG in Norwegian waters, and also one ropax ferry called Viking Grace sailing between Turku and Stockholm (see European Shortsea Network 2014). In addition, Tallink ordered first LNG powered ropax vessel in Feb.2015, and this to be used in traffic between Helsinki, Finland and Tallinn, Estonia. In addition, Finnish based Containerships has made an order of some number of container vessels to be delivered in the forthcoming years to be used at Baltic Sea Region.

Forslid et al. (2002) stress that a common worry in the Nordic region is that economic integration may lead to loss of industries and jobs in the peripheral regions. This has partly realized in Finland as being part of euro area has prevented devaluation of currency. Devaluation was earlier considerable aid to maintain competitiveness. The EU market is large and extensively concentrated from the viewpoint of paper export; a large portion of the largest printing houses and 250 million readers can be reached within a day's transport from paper mills located in Central Europe. This, however, is not the reality from the Nordic mills' perspective. The research question of how these fuel regulations on ships might influence the paper industry on national level has been neglected completely. This article aims to make a contribution for this in this research area.

\section{Characteristics of Paper Industry Costs and Profitability}

Paper deliveries to the four selected large export countries during the period of 2001-2009 are presented in Figure 1 (case paper mill). Total paper deliveries to these four export countries were circa 205,000 tons in 2001, and the number in 2009 was down to circa 127,000 tons, which is nearly 40 percent less than in base period. These four European countries together create the largest market for the mill. The declining demand was not as self-evident as the percentile may indicate; it could be seen more as a decrease trend, which fluctuates between years, showing also occasionally a slight increase in deliveries in some year. Hämäläinen and Tapaninen (2011) remind that the Finnish paper mills had great challenges to anticipate during 2001-2009 the trend of digitalization and the demand development in European paper markets. The price competition between mills became furious. This general trend in Europe has been quite substantially analogous with the results presented by Hämäläinen et al. (2015), and in the USA this development has started already about 15 years earlier. Some East European markets have grown and sustained their paper demand, which makes exception to the industry. However, nearly all actors in pure paper production are making deficits. Good example in this regard is Norske Skog (Hämäläinen et al., 2015), Norwegian based paper producer, which has been on significant deficits since year 2005 (at least until accounting year 2014, but also in the first nine months of 2015). 


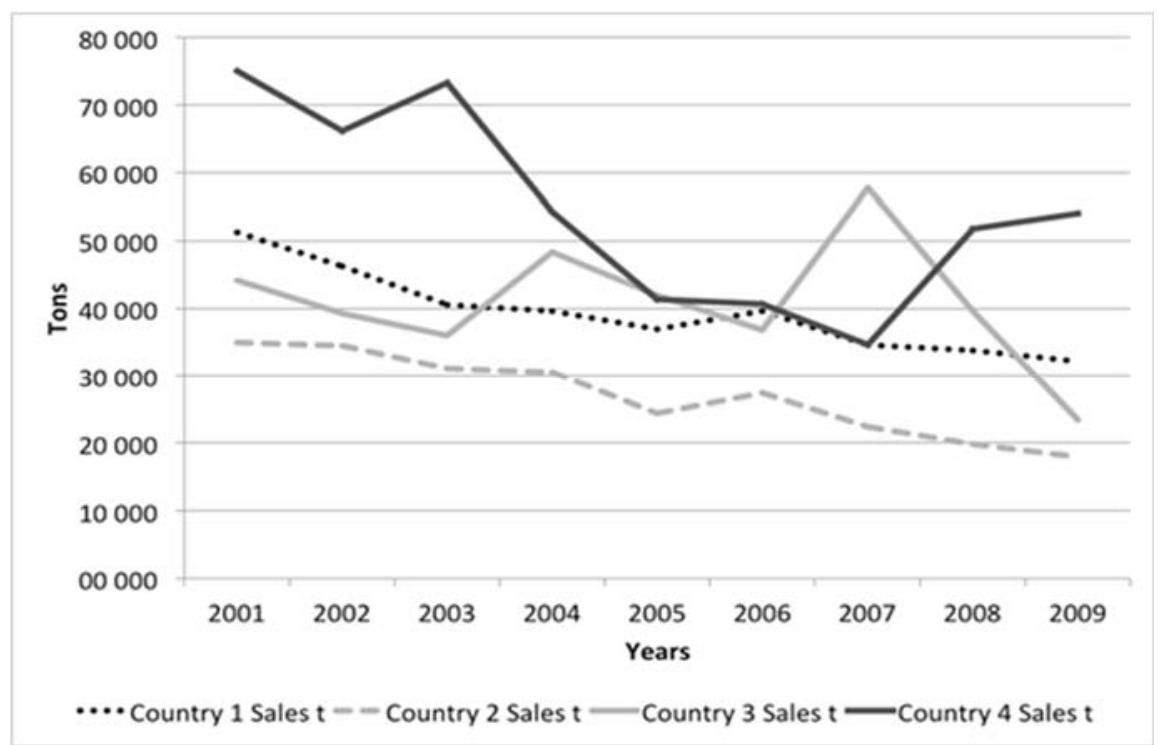

Figure 1. Development of the sales tons from case paper mill to four coastal export countries during 2001-2009

Figure 2 presents how the sales prices and manufacturing costs have developed during 2001-2009. During 2008-09, the paper prices slightly improved in three of the four countries. After 2009 the prices have remained at about the same level as in 2008-2009 or decreased slightly (see e.g. FOEX 2015; RISI 2015). The current prices of printing paper qualities in Europe are lower now than the prices were in 2009. During the study period from 2001 to 2009, the case mill has succeeded in holding direct and fixed manufacturing costs per ton at the same level, which certainly has helped to keep the mill running.

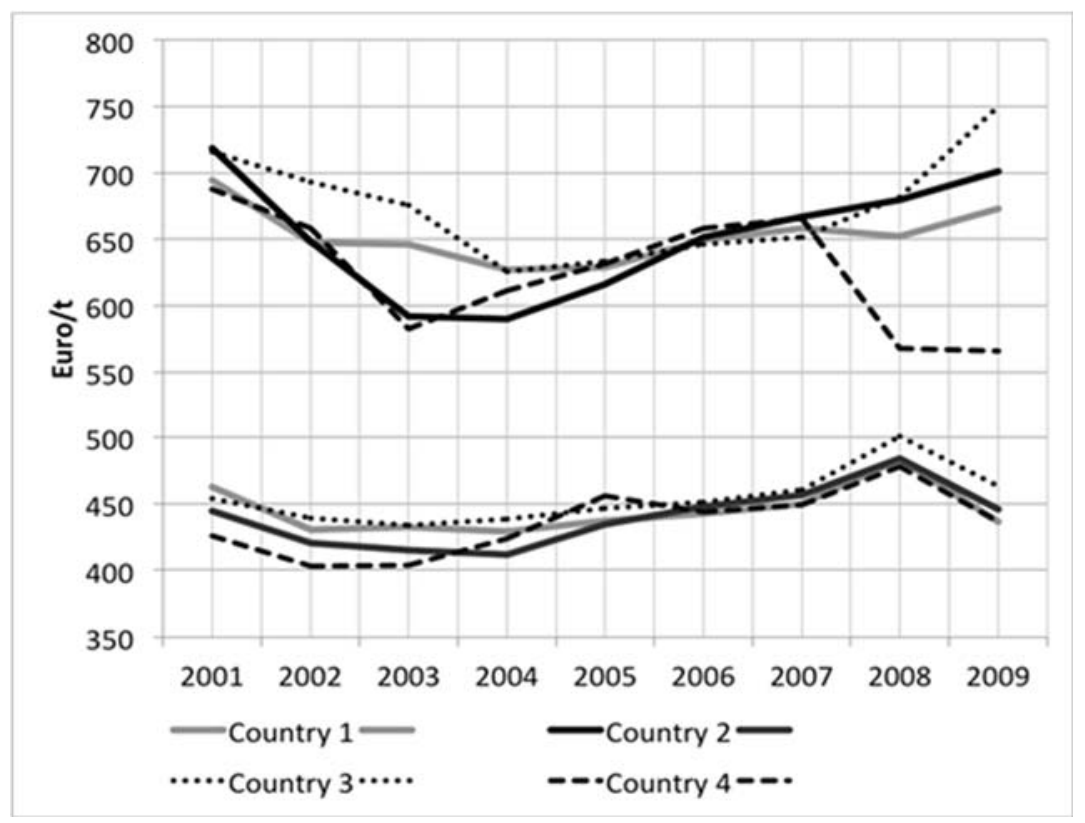

Figure 2. Development of the sales prices and manufacturing costs during 2001-2009 in four coastal export countries

From the view of transport, Figure 3 presents how the transportation costs have developed annually during 2001-2009. The country numbered as one is the closest to Finland and the country four is located farthest from it. The rise of oil prices mostly explains the cost increases of the transportation costs from 2001-2009, because sea freights are decisively bunker fuel dependent (Notteboom, 2011). After 2008 the freight costs have slightly decreased, but due to the existing high oil price the current transportation costs are on the same level as in 2008. Therefore, the Nordic paper sector is facing continuous difficulties in European markets, because the companies are not able to increase sales prices due to overcapacity. Figure 5 illustrates how sea freights are developed from Finland to these four countries, where paper products are 
transported by ships. The short sea shipping from Finland is an obligatory transportation mode, which cannot easily be replaced by other logistic modes. Finland is very much of an island from logistics perspective.

The peripheral location of the Nordic paper mill can be easily highlighted by analyzing and evaluating the transportation costs presented in Figure 3. Finnish mills must adapt in some way to the competition with European mills, which is mainly done with scales in production, and by producing socalled improved paper qualities. The transportation costs for foreign deliveries sometimes fluctuate quite widely, which is something the mills try to perceive. The export transportation costs $(€ / \mathrm{t})$ are on average ten times higher than those for deliveries to the home market in Finland (Hämäläinen 2011b).

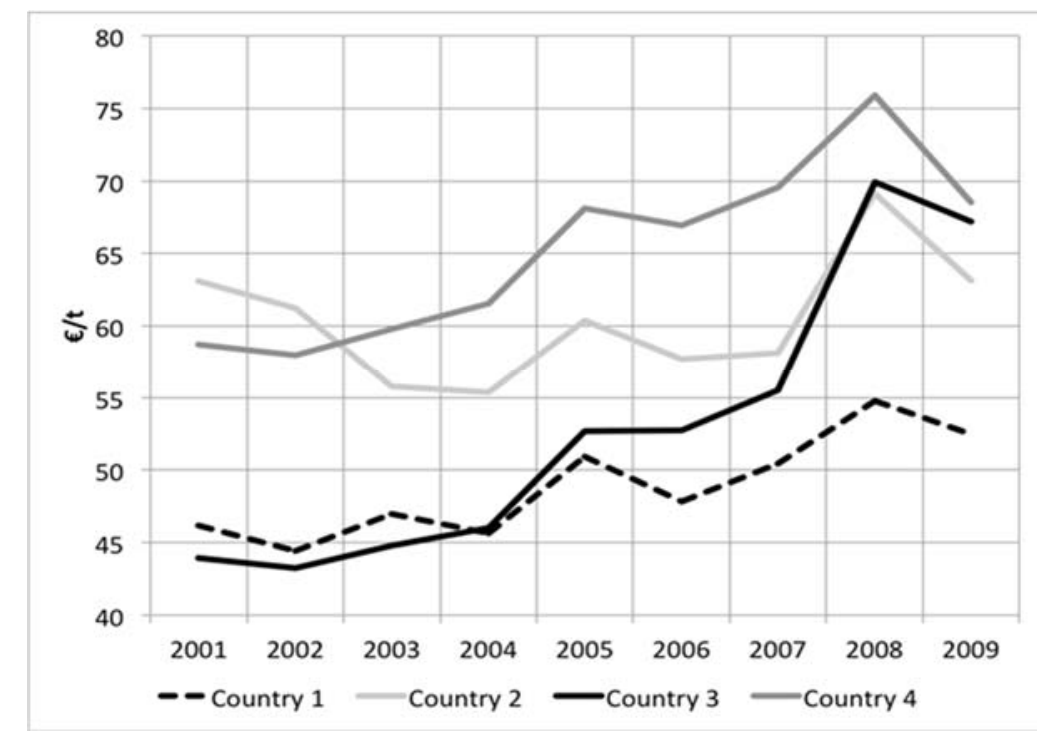

Figure 3. Development of the sea freights $€ / T$ to four large costal export countries 2001-2009

It is notable that domestic paper deliveries from case mill are only about 10 percent of the whole paper production, which indicates that export logistical issues are under continuous surveillance and controlling. Economic development (sales price less cost relation) has naturally been one of the main reasons for single machine lines and even for large paper mills to get shut down in Finland (Hämäläinen 2011b), and also all over Europe. As many academic regional and economic geography scientists (e.g. Weber 1909; Krugman 1995, and industry oriented scientists, such as Hämäläinen 2011b) have discovered, transportation costs can have a remarkable influence on margins, and as result also on industry location in the end.

\section{Anticipated Economic Impacts of EU Directive with MARPOL Annex VI to Nordic Paper Industry from 2015 Forward}

Figure 4 presents the estimated calculations on how transportation costs would change, if bunker fuel prices increased by $0,50,100$ or even 150 percent (see e.g. Notteboom 2011, but also Hilmola, 2015) from the existing price level. Furthermore, availability of the MGO may rise to be a problem due to political reasons in Europe. The fuel price in early 2015 (late March 2015; Bunkerworld, 2015) of the MGO (0.1\%) was around 510-530 \$/mt (900\$/mt in 2013/2014) compared to the more polluting grades having price of $300-310 \$ / \mathrm{mt}$ (600 \$/mt in 2013/2014). Early year 2015 has been gentle for sulphur regulation implementation, as oil price has declined (Brent) significantly in short amount of time from the level of 100-110 USD (late spring 2014) per barrel to approx. 50-60 USD per barrel (December 2014). Although, this decline would indicate that diesel prices at Baltic Sea declined in early 2015 as stricter sulphur regulation was implemented, however, actually prices in euros increased in euro terms in early 2015 roughly by 4-5\% (euro has been weak against USD lately). Jiang et al. (2014) anticipate in their recent study that the bunker price is subject to fast changes, and is thus greatly uncertain (similarly to Notteboom, 2011). The price gap between the MGO and the HFO can be expected to widen, when the sulphur regulations are introduced and global economy gains some momentum in late 2015, because then the MGO is in higher demand than the HFO. ISL (2010) and Entec (2010) anticipate that the LNG is feasible only for new vessels, and not retrofits. 
As global markets have experienced difficulties with trade after summer of 2015, especially with that of China and Europe, oil prices have remained low, and have actually been ranging between 40-50 USD per barrel. This has corresponded to changes of low Sulphur MGO $(0.1 \%)$ price, and in November 2015 prices were slightly below 400 \$ per ton. As euro currency has further weakened, this decline in oil prices has not been realized completely in finer MGO grades. Actually, in EUR terms price has declined from early 2015 by $15-17 \%$, however, in USD terms decline has been 21-24\%. Therefore, Figure 4 was modified to incorporate decline of $20 \%$ too. As could be noted, decline has very marginal effect on transportation costs. So, shadow of sulphur directive is still hanging around of North European exports. Benefits from cheap oil are marginal, and possibility to significant price increases still do exist.

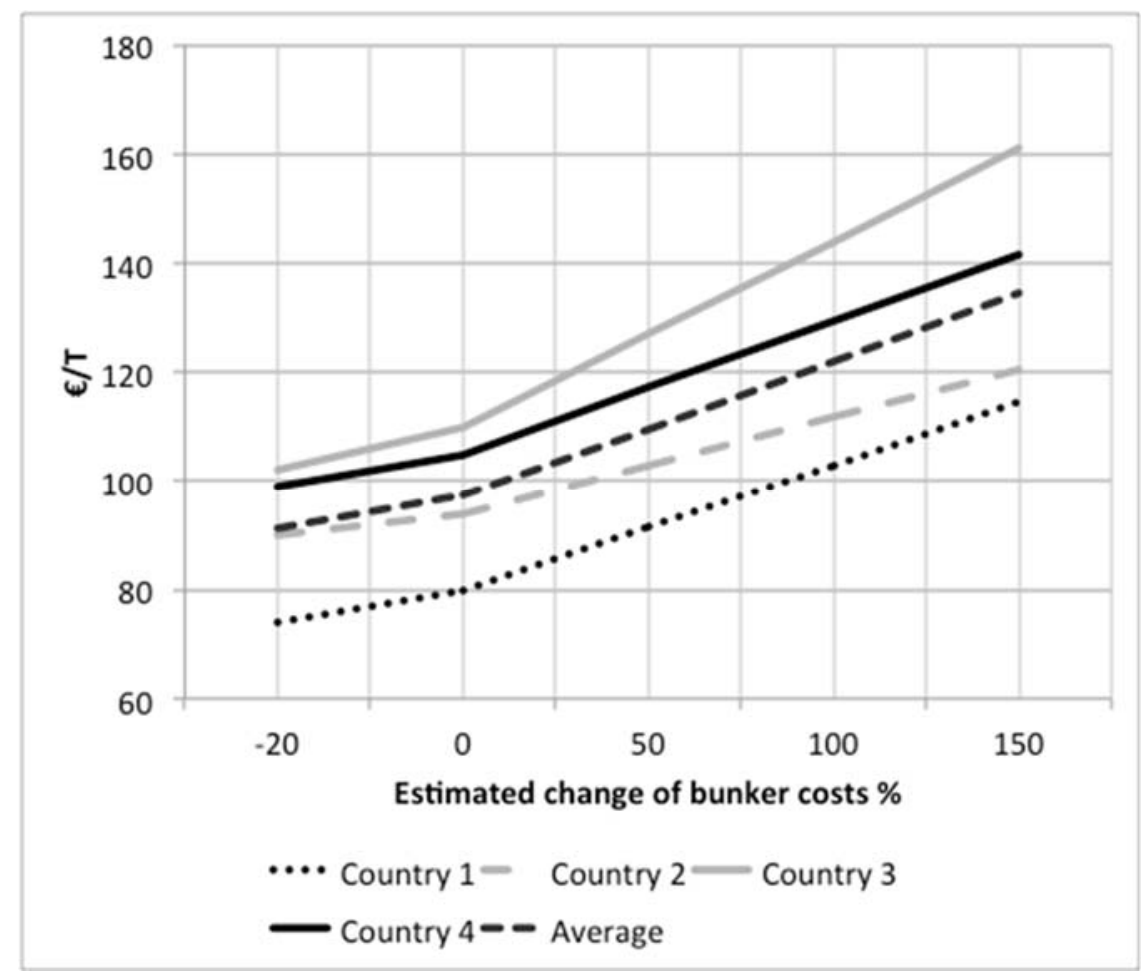

Figure 4. Forecast of the transport costs in $€ / T$ to four large coastal European countries in 2015 with estimated change of bunker costs ranging between $-20 \%$ to $150 \%$

MGO price levels in 2015 have been under discussions, especially lately in the Nordic countries, because of the SECA decision. In many earlier forecasting calculations, experts were anticipating high MGO price level in 2015 (see e.g Notteboom 2011; Kalli 2012; The Finnish Transport Safety Agency 2014). Problematic for logistics providers is that there are large variations in these estimations, which in the end impact sea freight costs. For example, Notteboom et al. (2010) have addressed that the MGO price could increase from 25 percent up to 200 percent when comparing it with the existing bunker prices (see also Swedish Forest Industries Federation 2009). Holmgren et al. (2014) indicate that the anticipated cost increases are so high that shipping companies are not able to absorb them, which in turn results in increased sea freight rates. A problem rises also in estimating the supply-demand balance of different distillates, such as the MGO and the HFO in the European markets, which may have a strong impact on the bunker prices. The Swedish Forest Industries Federation (2009) is concerned that this sulphur directive may have serious impacts on the competition of the heavy industry located in Northern Europe. Around 80 percent of the Nordic paper production is transported to Europe through short sea shipping routes, which go in or through the SECA. These extremely negative impact estimates are very much still present and valid, however, oil price decline in recent year has just postponed the negative implications within short-term.

Figure 5 presents the same four countries, which were analyzed from the perspectives of sales, deliveries and costs in the previous section. Figure 5 shows the results of the simulations on how the change of the bunker fuel from HFO to MGO can impact delivery gross margins to four countries. In order to examine the market areas forecasts on national level were revealed to expose the nature of transport cost variation. As noted earlier, these four countries play essential roles as market areas in Europe for the case mill, and also for the whole Nordic paper industry. As background information, current paper prices have 
been taken from the FOEX exchange values of 2013. Manufacturing costs are estimated to stay on the same level than in 2009. Transport costs are anticipated from the 2008 figures. The transport costs are heavily oil dependent, and the recent estimations forecast that in 2015 oil price will be on the 2008-level. Due to diminishing paper freight volumes (see e.g. Hämäläinen 2011b) from Finland to Europe sea freights have for long been under heavy competition, and therefore remaining at 2008-level. The real percentage of sea freight from the total transportation costs (€/ton) was obtained from the mill's cost management data. This percentage varies between countries depending mainly on the length of the short sea route between Finland and the destination country in question. The oil price of 2015 in US dollars was forecasted earlier to stay at a high level (CME Group, 2014). The latest US shale oil and gas findings, as well as supply may soften the increase of global oil price in long-term. As it was earlier addressed, that ship fuel costs for total operating costs vary heavily depending on ship type; the figures vary from 25 up to 65 percent (Notteboom, 2011). Mid-point of 45 percent was used as a cost-coefficient in the simulation calculations. Slow steaming, which is under discussions, may also lower the operating costs, but in this study, this factor has not been taken into account in the calculations. The paper sales volumes for 2015 to these four countries have been estimated from 2009 figures by using -4.5 percent as the annual negative coefficient. In Europe, paper consumption has changed from year to year between 0-7 percent, depending on the country. Western Europe is a saturated region, where paper consumption per capita has decreased since 2006 (Forestindustries, 2013).

In Figure 5, there are four countries, which illustrate how the estimated price change of marine fuel with four variables, $0,50,100$, and 150 percent would impact on gross margin. Value zero describes the starting point of the simulation. Figure 5 shows clearly that soaring fuel prices would impact directly to sea freight prices and in the end gross margins of exporting paper mill. The impact varies from market to market due to transport length, invoice prices of paper qualities. Also notable is the marginal effect of currently lower priced diesel markets - this characterizes well new directive, where benefits are basically cut off, and negative side is very sizable.

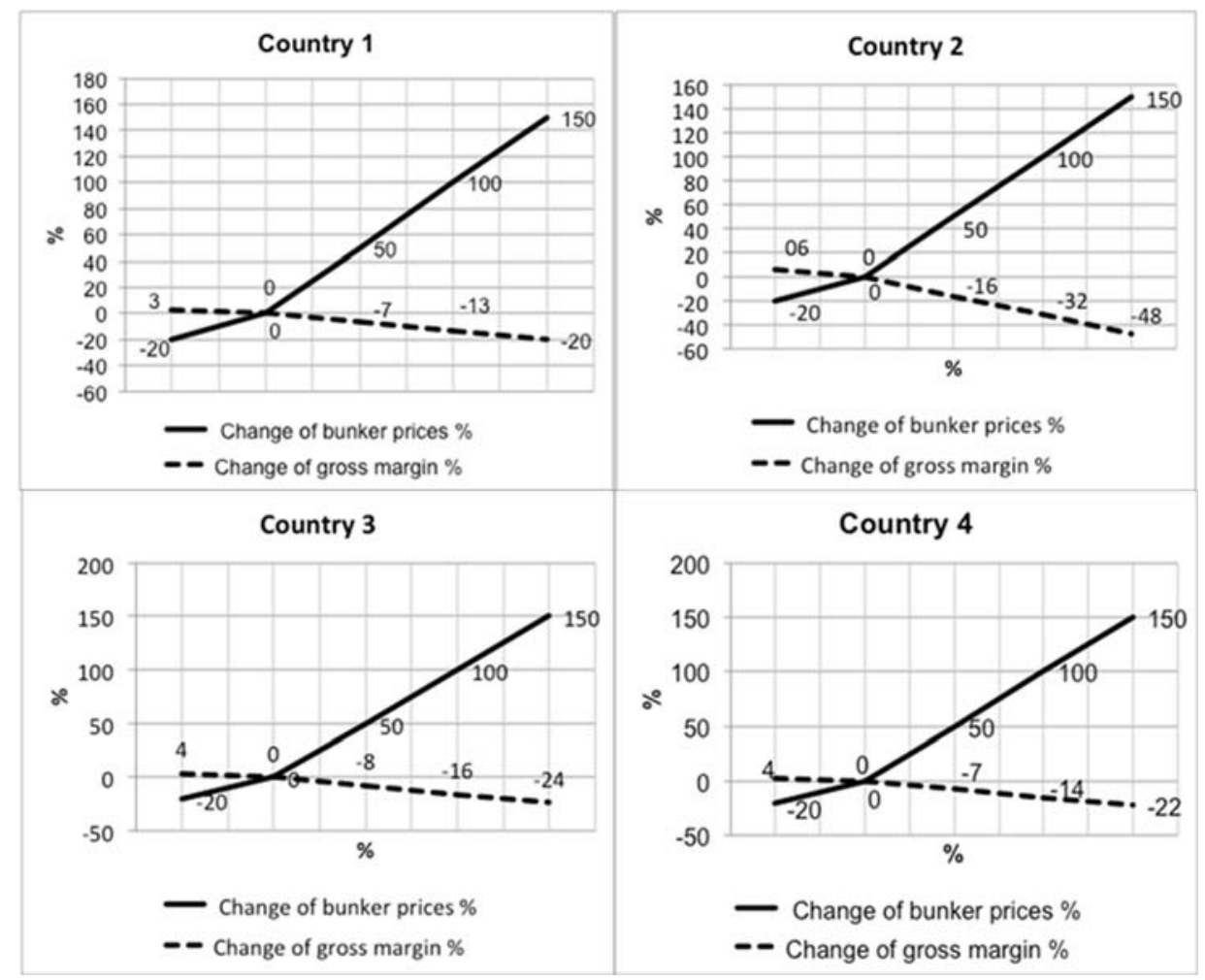

Figure 5. Change of the HFO (1\%) to the MGO (0.1\%) in 2015; change of fuel price -20, 0, 50, 100 or $150 \%$; impacts to profitability in percent

Figure 5 shows the simulation results with four different variables, and they highlight that gross margins will drop dramatically in the Nordic mills, if paper companies are not able to make any tangible improvements in logistic and manufacturing processes. The dramatic cost increase in an obligatory and essential logistic component, such as marine fuel, will impact gross margins directly. Hilmola (2013) argues 
that this, however, will not increase attractiveness of short sea shipping in the Baltic Sea; on the contrary, it creates a better possibility for road transport to take a considerably higher share in long-distance transport. This has actually materialized in years 2014-2015 as Finnish Estonian sea route has boomed and hinterland transports through Baltic States have increased considerably (Hilmola, 2014). The SECA decision will probably give an economic advantage to those European mills located in the center of market distribution and thus running close to large markets, where customers are mainly attainable through truck transportation. Thus, no extra warehouses are needed. Therefore, periphery mills will certainly suffer because of the SECA directive. Currently, customers' geographical position globally increases only slightly the average transportation costs (Hämäläinen 2011a), because deep-sea transit freights, even for heavy bulk products, are low.

\section{Concluding Discussion}

The aim of this article was to anticipate, how the EU's environmental regulations will impact the economic sustainability of a Nordic paper production. The results of this study highlight that the so called sulphur directive may have serious impacts on gross margins of a bulk paper company located behind short sea shipping (SSS) routes. The price estimations of the MGO vary substantially depending on the country. Sea transport researchers definitely have shared opinions that by changing from HFO to MGO, bunker costs may rise, or even double, when compared with the existing fuel prices. The rising bunker costs cannot be absorbed by shipping companies, and therefore sea freight prices are anticipated to increase about 20-50 percent (due to lower oil price, early 2015 witnessed rate increase of $10 \%$ ). This finding indicates that there will be a considerable economical downfall for the Nordic paper industry, because of the IMO and EU sulphur decision. It will be hard to adapt to and/or to eliminate these extra sea freight costs due to the nature of the paper business. There is a huge oversupply in the European paper market, and price increases are not easy to justify to customers. Naturally, the sulphur directive will heavily influence on all bulk industries, which are using short sea routes and are located in the SECA. The global price competition is rough in every industrial sector, and extra costs are not easy to compensate with higher market prices. As a result, this study reveals some interesting findings:

- There is a direct relationship between transportation costs and gross margins in the European market; its significance varies from country to country.

- Environmental decisions made by the IMO and the EU will give extra support for those paper mills located closer to markets in the center of Europe.

- The sulphur directive may increase sea freight prices significantly in the SECA, and thus affect all manufacturing industries negatively.

All paper mills located in the Nordic countries are in periphery and transport products to markets through multimodal routes. In that sense, the results of this study can, to some extent, be extrapolated to other mills and bulk industries, which have a low local demand, and which are located behind SSS to the main market. The export countries do not have any real and mutual significance to each other in paper sales or deliveries.

With the current oversupply situation, and due to higher transport costs from 2015 onward, it is more likely that paper companies may have to close some of their peripheral mills. This is in accordance with economic geographical theories from Weber (1909) to Krugman (1995), and with an empirical study by Hämäläinen (2011b). Transportation costs have effects on industry localization. It seems definite that the Finnish mills have lost many of their absolute and comparative cost advantages recently, and as implications to management, the following can be considered:

- Paper production oversupply should be minimized from the market.

- Efforts to make logistics from the Nordic countries to the European market more costefficient should be examined intensively.

- Ship owners and companies face difficult investment decisions in the near future on how to soften impacts of the sulphur directive on their operations.

- Alternative transport routes, such as the Baltic rail and truck corridors, should be examined from Finnish perspectives.

\section{References}

1. Alhosalo, M. (2013) Shipowners Barometer. Publications from the Centre for Maritime Studies, University of Turku, B 197, Turku, Finland.

2. Anonymous (2014) Interviews of logistics management of two large paper companies. 
3. Arlbjørn, J.S., Jonsson, P., and Johansen, J. (2008) Nordic research in logistics and supply chain management: an empirical analysis. International Journal of Physical Distribution and Logistics Management 6: 452-474.

4. Bruckner-Menchelli, N. (2009) Scrubbers versus Distillates. Sustainable shipping p. 24.

5. Bruckner-Menchelli, N. (2011) US Navy Targets 2016 for Green Fuel use. Sustainable Shipping. Petromedia Ltd., URL: http://www.sustainableshipping.com

6. Bunkerworld (2015) Bunker prices. Rotterdam, URL: http://www.bunkerworld.com /prices/port $/ \mathrm{nl} / \mathrm{rtm} /$

7. Cullinane, K. (2012) Chapter 4 An International Dimension: Shipping. In: Tim Ryley, Lee Chapman (eds.) Transport and Climate Change (Transport and Sustainability). Vol. 2, pp. 65-104.

8. CME Group (2014) Crude Oil Futures Quotes, URL: http://www.cmegroup.com/trading/energy/crude-oil/light-sweet-crude.html

9. Diesen, M. (1998) Economics of the Pulp and Paper Industry. Gummerus Oy, Jyväskylä.

10. Dieter, M. and Englert, H. (2007) Competitiveness in the global forest industry sector: an empirical study with special emphasis on Germany. European Journal of Forest Research, Vol. 126, pp. 401412.

11. Einemo, U. (2013) Methanol Sea Trial Expected to Start this Month. Sustainable Shipping. Petromedia Ltd., <http://www.sustainableshipping.com>.

12. Entec (2010) Study to Review Assessments Undertaken of the Revised MARPOL Annex VI Regulations, Commissioned by the Shipowners' Associations of Belgium, Finland, Germany, Holland, Sweden and the UK, London.

13. European Shortsea Network (2014) ESN - Way Forward SECA report.

14. EU (2005) DIRECTIVE 2005/33/EC OF THE EUROPEAN PARLIAMENT AND OF THE COUNCIL of 6 July 2005 amending Directive 1999/32/EC as regards the sulphur content of marine fuels. Brussels, Belgium.

15. EU (2012) DIRECTIVE 2012/33/EU OF THE EUROPEAN PARLIAMENT AND OF THE COUNCIL of 21 November 2012 amending Council Directive 1999/32/EC as regards the sulphur content of marine fuels, Brussels, Belgium.

16. FOEX (2015) Latest PIX index values with comments, URL: http://www.foex.fi/index.php?page=pixpulp (accessed 28.February.2015).

17. Forestindustries (2013) The Finnish Forest Industry in Figures. URL: http://www.forestindustries.fi/statistics/The-Finnish-forest-industry-in-figures-1274.html

18. Forslid, R., Haaland, J., Midelfart, I., and Knarvik, K. H. (2002) A U-Shaped Europe? A simulation study of industrial location. Journal of International Economics, Vol. 57, pp. 273-297.

19. Gallagher, T.L. (2010) Maersk to run biodiesel test. Journal of Commerce Online. Journal of Commerce, New York. URL: http://www.joc.com/maritime-news/maersk-run-biodieseltest 20100304.html

20. Head, K., and Mayer, T. (2004) The empirics of agglomeration and trade. In: Henderson, V., Thisse, J.-F. (eds.): Handbook of Regional and Urban Economics, vol. 4. North Holland, Amsterdam.

21. Hilmola, O.-P. (2013) Environmental and infrastructure payments and the future of road transports: case Tallinn-Warsaw. World Review of Intermodal Transportation Research, 4:1, pp. 55-72.

22. Hilmola, Olli-Pekka (2014) Growth drivers of Finnish-Estonian general cargo transports. Fennia International Journal of Geography, 192:2, pp. 100-119.

23. Hilmola, Olli-Pekka (2015) Shipping sulphur regulation, freight transportation prices and diesel markets in the Baltic Sea Region. International Journal of Energy Sector Management, 9:1, pp. 120132.

24. Hjelle, H.M. (2010) Short sea shipping's green label at risk. Transport Reviews, 30:5, pp. 617-640.

25. Hjelle, H.M., Fridell, E. (2010) When is short sea shipping environmentally competitive? International Association of Maritime Economists (IAME) Conference, Lisbon, 7-9 July, 1-18.

26. Holmgren, J., Nikopoulou, Z., Ramstedt, L., Woxenius, J. (2014) Modelling modal choice effects of regulation on low-sulphur marine fuels in Northern Europe. Transportation Research Part D, 28, pp. $62-73$

27. Hämäläinen, E. (2011a) Cost efficiency of supply chain in a Nordic paper mill - A case study. International Journal of Management, 28:3, pp. 945-958.

28. Hämäläinen, E. (2011b) Economic geographical analysis of the Finnish paper industry. Annales Universitatis Turkuensis, SER A11 - TOM, 263. Turku, Finland.

29. Hämäläinen, E. (2011c) Economic geographic characteristics in the Finnish paper industry - a case study. Fennia - International Journal of Geography, 189:2, pp. 63-75. 
30. Hämäläinen, E., and Tapaninen, U. (2008) Spatial characteristics of the transports in the paper mill's supply chain. Fennia - International Journal of Geography, 186:2, pp. 83-93.

31. Hämäläinen, E., and Tapaninen, U. (2010) Economics of a Nordic paper mill - case study. Industrial management and Data Systems, 110:1, pp. 5-23.

32. Hämäläinen, E., and Tapaninen, U. (2011) Accuracy of forecasting in a Nordic paper mill's supply chain: A case study. Norsk Geografisk Tidsskrift-Norwegian Journal of Geography, 65:2, pp. 104113.

33. Hämäläinen, Esa, Olli-Pekka Hilmola \& Lauri Hetemäki (2015) Fluctuating demand and its impacts to a paper producer: customer analysis. Expert Systems with Applications (forthcoming).

34. IMO (2014) International Maritime Organization, Sulphur oxides (SOx) - Regulation 14, URL: http://www.imo.org/OurWork/Environment/PollutionPrevention/AirPollution/Pages/Sulphur-oxides(SOx)---Regulation-14.aspx

35. ISL (2010) Reducing the sulphur content of shipping fuels further to $0.1 \%$ in the North Sea and Baltic Sea in 2015: Consequencs for Shipping in this Area, Commissioned by the German Shipowners' Association and Association of German Seaport Operators. Institute of Shipping Economics and Logistics, Bremen.

36. Jiang, L., Kronbak, J., and Christensen, L. P. (2014) The costs and benefits of sulphur reduction measures: Sulphur scrubbers versus marine gas oil. Transportation Research Part D, Vol. 28, pp. 1927.

37. Kalli, J. (2012) Päivitys: Laivapolttoaineiden rikkipitoisuus vuonna 2015, Selvitys IMO:n uusien määräysten vaikutuksesta kuljetuskustannuksiin. Turun yliopisto, Merenkulkualan koulutus ja tutkimuskeskus.

38. Kalli, J., Tapio, K. and Teemu, M. (2009) Sulphur content in ships bunker fuel in 2015: a study on the impacts of the new IMO regulations and transportation costs. Ministry of Transport and Communications, No. 31, Helsinki, Finland.

39. Koskinen, P. (2009) Supply chain strategy in a global paper manufacturing company: a case study. Industrial Management and Data Systems, 109:1, pp. 34-52.

40. Koskinen, P., Hilmola, O-P. (2008) Supply chain challenges of North-European paper industry. Industrial Management and Data Systems, 108:2, pp. 208-227.

41. Krugman, P. (1995) Development, Geography, and Economic Theory Returns and Economic Geography, The MIT Press, Boston.

42. Lähtinen, K. (2007) Linking resource-based view with business economics of woodworking industry: earlier findings and future insights. Silva Fennica, 41:1, pp. 149-165.

43. Nordea (2013) New forecasts: Oil prices creep higher, URL: http://research.nordeamarkets.com/en/2013/03/19/new-forecasts-oil-prices-creep-higher/

44. Notteboom, T. (2011) The impact of low sulphur fuel requirements in shipping on the competitiveness of roro shipping in Northern Europe. WMU Journal of Maritime Affairs, 10:1, pp. 63-95.

45. Notteboom, T., Delhaye, E., and Vanherle, K. (2010) Analysis of the Consequences of Low Sulphur Fuel Requirements. Report commissioned by European Community Shipowners' Associations (ECSA).

46. RISI (2015) Resource Information Systems Inc. Database for Pulp and Paper, available at URL: http://www.risiinfo.com/ (accessed 28.February.2015).

47. Swedish Forest Industries Federation (2009) Information Paper - Consequences for the Pulp and Paper Industry due to New Sulphur Regulations for Ships, 18 June 2009.

48. The Finnish Transport Safety Agency (2013) Merenkulun uusien ympäristömääräysten aiheuttamien kustannusten kartoittaminen, Liikenteen turvallisuusvirasto (Finnish Transport Safety Agency) julkaisuja, 24/2013.

49. Weber, A. (1909) Über den Standort der Industrien. Tübingen. English translation by Freidrich, C.J. 1929. Alfred Weber's Theory of Location of Industries. University of Chicago Press. 